\title{
The Youth from Brasilia in an Online Newspaper
}

\author{
By Virginia Meirelles*
}

In this paper we intend to understand the process of individualization of youth in the urban space of Brasilia and its relationship to language, considering how the urban space was configured and its history. For this, we analyze the titles and the comments of articles published by the online version of Correio Braziliense, the largest selling newspaper in the Federal District, Brazil. This research is embedded within a larger project that takes as its theoretical assumption discourse analysis to understand the relationship between language, youth and society in/from Brasilia. Discourse analysis takes as theoretical and methodological principle that the interpretation in the text as key to understanding how this text is produced and how it produces meaning. Language is a way of signifying in which meaning produces and reproduces social and historical processes. So, the image projected by the city and society today is the result of a set of social and historical events, a fact that makes it important to know the history in order to understand the meanings of contemporary discourse. It is also necessary to examine the conditions of production to define the relationship between youth and the urban space and to understand the division of the senses in this space. At the same time, because the work is to analyze comments posted on an online journal, this new form of language is considered. In the digital world, the figure of the author and the category of work appear scattered; texts are available in electronic media and will allow dismembering and recombining; the readers, the reading process, the notion of work have changed. It was found that in this online newspaper, the readers are not really reacting to the information present on it but to the social and historical settings of the construction of the capital city.

\section{Introduction}

This paper is part of a project coordinated by Mariza Vieira Silva that takes Discourse Analysis (DA) as theoretical framework in order to understand the relationship between language, youth and the community in Brasília. DA establishes as theoretical and methodological principle that the interpretation contained in the text is basic to understand how it signifies, once language is a relative autonomous system that is affected by history. In other words, DA treats language not as a code, but a means of signifying in which social and

*Professor, University of Brasilia, Brazil. 
historical effects are shaped and reproduced. As such, the image by today's city and by today's society is the result of a series of social and historical actions which are imprinted in language materiality. As well as considering the utterance, it is important to examine how the speaker associates, discursively, with the addressee and how both connect in and with the urban environment. Thus, it is essential to analyze the conditions of production to recognize the relationship between youth and urban space, and also to comprehend the emerging senses.

Developments in information technology today has made it possible to have simultaneous interaction with the writer although the correspondents may not share the same location. The concept of 'author' and the category of written document are now vague once the texts available in the electronic environment are fragmented and can be recombined, cut, joined, amended and tailored as separate fragments. In an interview to Torres (2011), Chartier mentions that in the electronic environment the text is not connected to the whole to which it belongs'. The reader, the act of reading, and the perception of written work have changed since on the web everything is fragmented. As such, the imaginary relationship of the subject with language and with knowledge has changed.

Dias (2011) points out that, in order to understand the connection and significance of the urban and the digital space, we need to consider the social relationships, the effect of meaning, the functioning of ideology, the conflicts, and the tensions involved in that correlation. In other words, Dias tries to understand how urban space and electronic means signify and relate by applying DA principles since materiality is in the process in which language, ideology and unconscious engagements are part of the discourse. For that reason, the moment a subject is affected by a new technology; there are consequences in language, culture and memory, since those are the essence of the production of signification. As it is in the urban space that the technologies signify and by understanding the use the subject makes of them, we may produce knowledge about the subject and about the organization of the urban connections.

In view of that, the aim of this paper was to comprehend how the discourse of the media signifies the youth in the urban space in Brasília. Our starting point was the description and analysis of the linguistic materials for identifying the discursive processes there in and understand the effects of meaning that are part of them. The manner the urban space was constructed has shaped an image in relation with the symbolic and the political in history; therefore, by understanding how the individuals relate with that space, it was possible to relate to the knowledge of how its organization affects them. The corpus was built using the online version of Correio Braziliense $e^{l}$ and the analysis was done on the headlines connected to the youth and the comments those articles received.

\footnotetext{
${ }^{1}$ http://www.correiobraziliense.com.br/
} 


\section{Production Text}

Correio Braziliense is the most read newspaper in Brasília and is available online. That online version makes, or would make it possible to have a greater access to the newspaper allowing one to comment on the available articles (examine further analysis).

The journalists that write in the newspaper are responsible for the amount and viewpoint of the information that is provided. They also decide what is relevant as news and thus what appears in the newspaper and what should not. On the other hand, the reader probably lives in the Federal District, but it would be difficult to say where the person lives exactly - in Plano Piloto (upper-class neighborhood), or in the satellite-cities.

Caderno Cidades is the section that brings information about the city. It categorizes the news in topics (housing, security, health, elections) or neighborhoods (Asa Norte, Sobradinho) as illustrated below in the opening page (Figure 1). The more important articles are shown in a special spot and usually include photos; the others come below in a list. The relevant news is usually related to political issues, wealth or leisure. It was observed that the news connected to the satellite-cities is usually about violence and illegal events.

Figure 1. Opening Page from Caderno Cidades Online

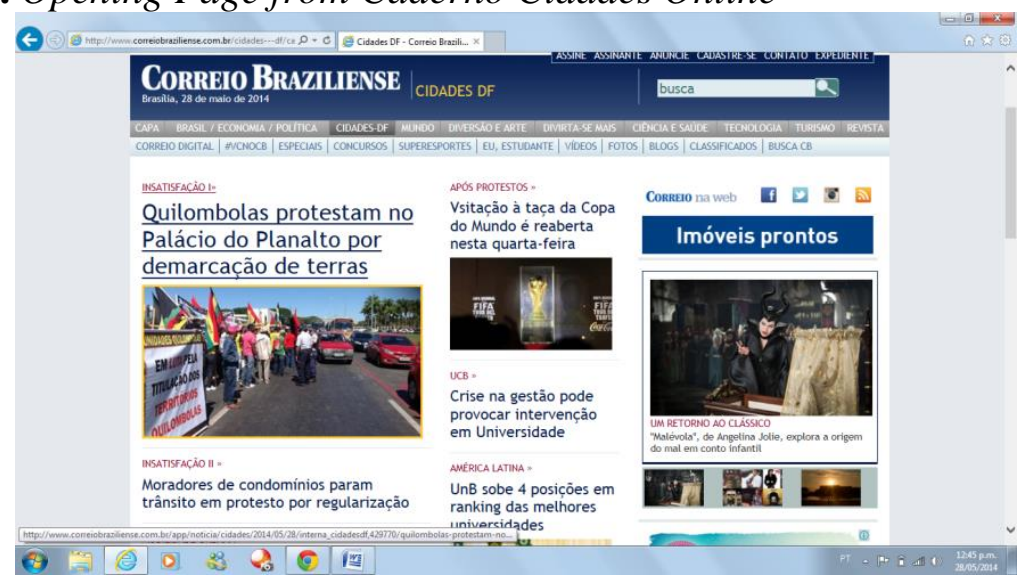

That list appears beneath the important articles and is organized in two ways: chronologically and by most read. Each list shows (highlighted) the number of comments received. That way, the reader would theoretically be able to decide which article to read.

The fact that the journalists decide which information makes piece of news and which position it receives is part of the ideological interpretation that produces meaning and which DA strives to understand. Dias (2011) states that, 'the meanings about the city circulate in many forms. One of them is in the images the media present'. Consequently, if we consider that the news appears in a certain position and is already connected to a particular topic, it becomes clear that the readers are not completely free to choose what to read. Moreover, 
by giving the number of comments and by including photos, the newspaper is already guiding the choices for the readers.

To include a comment, the readers need to fill a form and accept the Terms of Use that limits the assumed advantage of being anonymous on the web. However, that form allows the readers to maintain their real identities as secret (from the public) and would make them feel at ease to state their opinions without restraint. Even though, the readers make a compromise not to use a false identity; it is well known that the web is a gloomy field where insecurity rules (Kemmer Cernev, Corrêa Leite, 2005).

The research issue - production of meaning about the urban youth by the media - relates to a more ample context that of the fragmentation and separation of the urban space encouraged by the social isolation in the capital. According to Vidal (2009), the proposals to relocate the Capital city, from Rio de Janeiro to the central part of the country, were put forward in the XVIII century. During the Republic years, there were two different views regarding the organization of a more modern Brazil: a project supported by plantation owners, and a project supported by the urban middle-class and the military. Either project wanted to conceal or camouflage the population, somewhat in the memory or within the cities (Vidal, 2009, 103).

Campos Gouvêa (Paviani, 1996, 231) states that Brasilia is an example of premeditated social apartheid, in which the urban pattern aimed at 'making people's lives more difficult, and making social control easier'. Additionally, Stumpf and Santos (Paviani, 1996, 50) say that the city was not planned for blue-collar workers and Doyle (Paviani, 1996, 117) explains that when constructing Brasilia, the government wanted to eliminate the shantytowns, to put the problem of poverty away from the sight of the community.

One third of the workers who came to build the city were supposed to stay, and the satellite-cities were supposed to appear after the construction of the capital city. Notwithstanding, on the inauguration of Brasilia there were 70000 workers living in eight satellite-cities. That is, since the establishment of Brasília, the central part of the urban space has been set aside for the privileged and the satellite-cities have been kept as areas for the poorer. Nowadays, 70\% of the population of the Federal District lives in those cities.

\section{Web Journalism: Egaletarianism of Information?}

The comments analyzed were posted from August 2011 to May 2012 to articles on the subject 'youth'. The first proposal was to analyze the articles published during one year. Notwithstanding, it was observed that during the second semester of 2011, the news adjusted perspectives: before, the frequent topic was wealth; now, it is violence. As it has been observed, the decision of what is a piece of news is not neutral or accidental; it is part of the conditions of production of meanings and subjects. Guimarães $(2001,16)$ states that 'something becomes an incident, [...] according to the interests involved in the event' and defines that approach as the 'wiping away of knowledge resources' 
(op. cit, 13). For some reason, after the second half of 2011, the interests were not for showing the quality of life in Brasilia, but in presenting an increase in violence. In 2012, the news on violence was almost the only one published.

Primo and Recuero $(2003,58)$ identify different hypertexts: (a) potential hypertext - sets the paths and movements a reader can make and does not allow any kind of transformation. The text acts on the reader, but it does not change its form and content. The newspaper layout is very similar to the printed text, but it offers some tools as forums and quizzes; (b) cooperative hypertext allows the readers to modify the text. Readers have and receive impact form the group and build their own product together; (c) cut and paste hypertext requires management and gathering effort to put the work together. It is not the result of debate and cooperative work.

Hence, not many hypertexts are the result of cooperation. Occasionally, tools such as comments allow the reader to leave observations about the published articles. We include Correio Braziliense in the first group, potential hypertext, as the readers are allowed to include comments, but not to change or add any material to the article, being limited by the interpretation the newspaper offers.

Primo $(2003,132)$ presents the term mutual interaction; a kind of bond built by the participants during the process that has an impact on the evolution of subsequent associations. Primo and Trasel (2006) define two types of interaction in web journalism: (a) reactive interaction - when the reader cannot modify the content, but can answer a quiz; and (b) mutual interaction - when there is negotiation among the participants in order to write and edit the text. From DA's viewpoint, Correio Braziliense does not really promote reactive interaction once it has a space for comments but does not ask for the readers' opinion. Nonetheless, sometimes there is a sort of mutual interaction as described by Primo (2003) since some of the remarks have an impact on other readers who subsequently comment on them.

To sum up, there is not a great deal of interaction among the readers of the Correio Braziliense, as had been observed by Primo \& Recuero (2003), Primo (2003) and Primo \& Trasel (2006) for other online sites. The tool 'comments' limits the kind of participation to posting observations, where most readers comment on the article and usually do not read carefully the comments posted by other people. Being so, Trasel (2007) would say that there is no interaction among the readers; however, from the perspective of DA the very fact that people choose to read articles that received more comments is a kind of interaction. In addition, even when the readers pore over articles, they are interacting with the writer. Furthermore, Primo and Trasel $(2006,47)$ say that this tool was abandoned by the newspapers because of the many aggressive comments posted there. Hence, information technology researchers maintain that there is no interaction among readers; nonetheless, DA argues that if the tool has been eliminated because of the kind of observations included it means that there is interaction.

For that reason, the newspaper asks the users to agree to a Terms of Use, in which there are specific references to aggression. Those terms inform that the 
newspaper can eliminate remarks that do not follow the 'good manners', and limit the possibilities of interaction and the spontaneity in communication. This contradicts the assumed freedom of speech that is fostered by the web; the readers may post whatever they want, nonetheless the newspaper can eliminate the comments as it pleases - as is written in the Terms of Use. Accordingly, the newspaper maintains censorship of what is being posted.

Primo \& Trasel (op. cit) state that 'production and reading are altered in the printed and online newspaper according to the conditions of each means' because they agree with Mc Luhan's metaphor that 'the medium is also the message', idea shared by DA. Therefore, we compared the printed with the online version and observed that in the second the articles are not complete; only subscribers to the newspaper have access to the complete articles. Hence, it is possible to demystify the widespread idea that the web gives unrestricted and unlimited access to information. In contrast, it reproduces social fragmentation. The same kind of division that grants access to written information to those who can pay, is reproduced in the online environment where only those who pay have the right to read the complete article. Social stratification and ideology are disguised in this way of giving the news; internet does not give visibility to everything and is not democratic, as it is commonly alleged. Consequently, the web is not a passport to free and unrestricted information.

Still another contradiction, already mentioned, is the well-known identity issue. Even though it is possible to identify the authors of the texts, it is difficult to say if they are using a username as their authentic name. Theoretically, the web makes it possible to choose a different 'identity', the fact that would give the readers autonomy to express whatever they want to say. Nonetheless, they have already signed a Terms of Use that asks to restrain from posting certain comments. That is antagonistic; on the one hand, secrecy would make it possible to 'say' everything a person wants to say. On the other hand, there is a document that limits that possibility (given that theoretically the newspaper knows who the reader is). In other words, the users may not be able to say everything they want.

The headlines and comments considered in this paper were published from October $31^{\text {st }}$ to November $6^{\text {th }}, 2012$ and communicate the aggression to people by youth in different places of the Federal District. From October $31^{\text {st }}$ to November $4^{\text {th }}$, eight articles were published about a young person that was beaten when leaving a party in Lago Norte (upper-middle class neighborhood). As a whole, the sequence received 107 comments. Again, on November $5^{\text {th }}$, an article about a teenager and a woman being shot in front of a school in Santa Maria (satellite-city), received no comments. The following day, November $6^{\text {th }}$, an article about a youngster that was imprisoned because he had killed an opponent that was threatening him received one comment.

The series of articles received an important position in the opening page of the section, whereas the other two headlines were listed below. Also, each headline related to the party was accompanied by a photo (the aggressor or the assaulted); the other had no photos. That way the newspaper is already 
showing which news is significant and which is not. When that is considered, the number of comments received by each article is not unexpected.

The first three articles appeared on the same day, October $31^{\mathrm{st}}$. Agressores comemoraram espancamento de jovens no Lago Norte, diz testemunha (Aggressors celebrate beating young person in Lago Norte, says witness) received 29 comments like: 'Those that have everything are not happy with the simple things of life and find entertainment in bizarre things'. Eight comments called the attackers 'daddy spoiled', 'cowards', 'pumped' and 'playboys'. Many readers mentioned the fact that nothing would probably happen to the aggressors because things would be settled up by bribing. One comment linked the event to the policy of the only public (and free) University in town that assists colored people in entering the University. One person, who said he was a criminal lawyer, stated that the other readers are being influenced by the 'manipulative media' since the article did not say why the person was beaten. As such, he suggested the readers should analyze the facts before judging the aggressors. The lawyer probably refers to the fact that the newspaper is already interpreting the events that it is presenting when it says that the aggressors celebrated an assault that took place after a party. The article points to the inconsistency between a party and an aggression, also it refers to a witness, fact that makes the scene more dramatic and convincing.

The observations posted are, as the 'criminal lawyer' said, influenced by the way the newspaper is giving the news. By placing a witness in the scene, by using the word 'aggressors', by stating the place where the aggression happened, the newspaper is already interpreting the facts and producing meaning. The readers react to that interpretation and to that meaning by reproducing significance. Thus, they list ideas that are associated to the kind of life that the youth form that upper-middle class neighborhood is supposed to have. Also, they mention bribing, which is considered a normal practice among them in order to avoid punishment. And last, someone links the event to the policy the University has, suggesting that it is shaking social status quo.

The second article, Universitário suspeito de agredir adolescente em festa é indiciado (University student suspect of aggression to a teenager at a party is indicted) received 33 comments. The aggressor is now described as a suspect (the newspaper is not sure anymore) and also a university student. Thus, he is an adult that attacked someone that is not an adult yet. The witness is not mentioned anymore. Also, the first article said that the aggression took place after the party, now it is described as having occurred at the party. There were 6 comments to this article, like 'People who live in Brasília know that these young people are like that' and a list of other aggressions that have happened: 'burning native people and beggars' and 'attacking people in group'. Two readers mentioned the fact that the police is 'on strike for the poor'. Once more, people mentioned that the aggressors are 'spoiled brats' and 'pumped'.

Again, the remarks are influenced by the way of interpretation of the facts and production meaning. Consequently, the readers continue to produce and reproduce what has been socially and ideologically established. The uppermiddle class youth assaults people, their parents bribe the authority, the police 
do not work for the poor but they are working on this case because it involves rich people.

Next, Três pessoas são identificadas por envolvimento em agressão a jovem (Three people were identified as involved in the aggression to the young person) received 13 comments. Instead of one adult university student attacking a teenager, the newspaper is presenting again three people assaulting just one teenager. The interpretation should be 'it is not fair', and the readers react accordingly. Comments insist on the fact that it is 'just playboy fight, things can be settled with a nice dinner'.

On the second day (November, $1^{\text {st }}$ ) the headline was Laudo confirma que agressor de jovem no Lago Norte mentiu em depoimento (Evidence confirms the aggressor of young person lied in testimony). The newspaper presents legal evidence that proves that the aggressor made a false statement. Two concepts are fundamental, 'legal evidence' and 'lie': the suspect of aggression is now described as a liar to the legal system. There were seven comments that maintain the idea that 'this is another example of the brutality of the youth in Brasilia that is not going to be punished'.

The fifth article quotes 'Mirava na minha cabeça, para matar', diz jovem agredido no Lago ('He aimed at my head' says beaten boy in Lago). Still, the perspective of the beaten boy is given the more prominence. The cruelty of the aggressor is such that the person aimed at the boy's head, which is the most fragile part of the body. The article received nine comments, among which 'the aggressors are free because they probably are daddy's brats, if they were sons of a Joe Doe they would be behind the bars. That is the big difference. The law is not equal for all.'

The sixth article (November $1^{\text {st }}$ ) Acusado de espancar jovem no Lago Norte cai em contradição (Indicted of beating young person in Lago Norte contradicts himself) received four comments. The university student who was described as an aggressor, liar, coward and cruel person is now portrayed as contradicting himself. Still, the perspective is diminishing the aggressor and qualifying the assaulted boy. All comments follow the same principles: the youth form the upper-middle class act like this because they are 'spoiled brats' that like to mug people and will receive no punishment because their parents will bribe the police.

On November $3^{\text {rd }}$, Jovem espancado no Lago Norte vai realizar cirurgia nesta tarde (Assaulted young person undergoes surgery this afternoon), received only a 'get well soon' message. Also, Jovem que foi espancado busca autorização para fazer o Enem no hospital (Assaulted young person gets permission to answer the University Entrance Exam in hospital) was commented by two people. One mentioned the fact that if he had been studying, he would have not been beaten. The headline implies that the boy is very brave since he is in hospital and is worried about his future.

The last article of this series of news appeared on November $4^{\text {th }}$. There were nine comments posted to Espancamento de jovem de 18 anos repete histórico de agressões no DF (18 year-old boy's assault repeats the history of aggression in FD). Four of them mentioned impunity. Another one pointed out 
that aggressions are not restricted to Brasília; Rio de Janeiro and São Paulo also have those actions. The article that closes the series reminds people that in Brasilia assaults are common and brings a list of when, where and who was assaulted. The aggressors were always upper-middle class youngsters. This will be the lasting idea the newspaper provides.

The comments that were given to this series were influenced by the way the new were presented. The 'witness', the word 'aggressors', the place where the aggression happened and the number of articles offered already show that the newspaper's ideology is one that considers high-class youth as 'spoiled'. The readers respond to that ideology by reproducing meaning. In view of that, most of them mention activities (bribing, assaulting, getting pumped and corrupted youth) that are taken as connected to the upper-middle class way of life. A further fact is that from the first article on, the perspective is that of the assaulted.

On November $5^{\text {th }}$, Mulher e adolescente são baleados em frente a escola de Santa Maria (Woman and teenager shot in front of a School in Santa Maria - satellite-city), did not receive any comments. By comparing the number and quality of comments received by the previous series, the question arises: does the fact that people are shot in front of a school does not deserve comments? Is beating a person after a party more serious than shooting people in front of a school? The school environment suggests the idea of studying, of cultural accomplishment, not shooting. Why were there no comments? Is it possible that the lack of comments is the result of the kind of interpretation already present in the newspaper? We believe that the answer for the last question is yes. The interpretation given already implies the kind of reaction the readers would have: when reading about an aggression after a party in an upper-middle class neighborhood, it should be one of disgust and astonishment. It is not acceptable to assault a young person, probably belonging to the upper-middle class, in a party at a fashionable place of the city. Whereas, the fact that people are shot in a satellite-city would not be a consequential event from the ideological viewpoint the newspaper adopts and within the history of the construction and development of the city. As it was observed before, the news connected to the satellite-cities is about violence.

The last article was published on November $6^{\text {th }}$ and stated: Após ser ameaçado, jovem mata rival e acaba preso em Sobradinho II (After being threaten, young person kills opponent and is in jailed in Sobradinho II satellite-city). The only comment was that this was legitimate defense. Two aggressions are mentioned here; first, the threatening; second, the murder. Apparently, none of them was interesting to the reader.

\section{Conclusion}

As it has already been observed the newspaper guides the readers' interpretation and that the social and historical events contribute to the interpretation newspaper and readers produce and reproduce about the city. 
Thus, the fact that the last two events were not commented is already part of the interpretation of information done by the subject.

Hence, it is obvious that the history of the city and the interpretation of the facts, already present in the articles, influence the number and characteristic of the comments they receive. They illustrate the options the readers are influenced to make. The comments to the sequence of articles related to the beaten person are many, while the other two articles did not share the same importance. By analyzing the number and quality of the comments it was possible to understand that they are the manifestation of an ideology, the memory of what and how to say things, and the memory of history that represents already established judgments. In Orlandi's words (2004, p 83):

'A cidade é um espaço significante, investido de sentidos e de sujeitos, produzido em uma memória. Quando se fazem certos gestos em relação a essa memória, se está transformando, modificando, ou não, essa memória. Ou se está ratificando essa memória ou se está rompendo com ela.'

\section{References}

Dias, C. 2011. e-Urbano: a forma material do eletrônico no urbano (e-Urban: the material pattern of the electonic in the city). In. Dias, Cristiane. E-urbano: Sentidos do espaço urbano/digital (e-urban: meaning of urban/digital space) [online]. 2011, http://www.labeurb unicamp.br/livroEurbano/ Laboratório de Estudos Urbanos - LABEURB/Núcleo de Desenvolvimento da Criatividade NUDECRI, Universidade Estadual de Campinas - UNICAMP, Brazil.

Guimarães, E. 2001. Acontecimento para a grande mídia e a divulgação científica (The event in mass media and scientific publishing). In. Produção e circulação do conhecimento (Knowledge production and spreding). v. 1 Estado mídia e sociedade. Pontes, São Paulo, Brazil.

Kemmer Cernev, A. and Corrêa Leite, J. 2005. Segurança na internet: a Percepção dos Usuários como Fator de Restrição ao Comércio Eletrônico no Brasil (Internet security: the perception the users as a means of limiting e-commerce in Brazil). In Proceeding of the XXIX Encontro da ANPAD, (September), Brasilia, Brazil. $\mathrm{http} / / / \mathrm{www}$.anpad.org.br/evento.php?acao=trabalho\&cod_edicao_subsecao=30\& cod_evento_edicao $=9 \&$ cod_edicao_trabalho $=25 \#$ self.

Orlandi, E. 2004. Cidade dos sentidos (City of meaning). Pontes, Campinas, Brazil Pontes.

Paviani, A (org.) 1996. Brasília: moradia e exclusão (Brasilia: housing and seclusion). Coleção Brasília. Editora UnB, Brasilia, Brazil.

Primo, A and Trasel, M. R. 2006. Webjornalismo participativo e produção aberta de notícias (Participative webmedia and outspread production of the news). In Contracampo Revista do Programa de Pós-Graduação em Comunicação da Universidade Federal Fluminense. v 14, Rio de Janeiro, Brazil, 37 - 56. http://www6.ufrgs.br/limc/PDFs/webjornal.pdf.

Primo, A. 2003. Quão interativo é o hipertexto?: Da face potencial à escrita coletiva (How interactive is the hypertext?: From the potential stage to colective 
composing). In Fronteiras: Estudos midiáticos, v. 5, n. 2, São Leopoldo, Brazil, 125-142. http://www6.ufrgs.br/limc/PDFs/quao_interativo_hipertexto.pdf.

Primo, A. and Recuero, R. 2003. Hipertexto Cooperativo: Uma análise da escrita coletiva a partir dos Blogs e da Wikipédia (An analysis colective composing froms Blogs and Wikipedia). In Revista FAMECOS: mídia, cultura e tecnologia, n. 23, Pontifícia Universidade Católica do Rio Grande do Sul, Porto alegre, Brazil, 54-63. http://www6.ufrgs.br/limc/PDFs/hipertexto_cooperativo. pdf.

Trasel, M. 2007. A participação do público no Wikinews e no Kuro5hin (Readers participation in Wikines and Kuro5hin). In Revista E-compós, Brazil. http://www.compos.org.br/files/11ecompos09_MarceloTrasel\% 20.pdf.

Torres, B. 2011. Historiador Roger Chartier diz que a web mudou a forma de escrever (Historian Roger Chartier says the web changed our way of writing). In Jornal do Brasil, Cultura, Rio de Janeiro, Brazil. http://www.jb.com.br/cultura/ noticias/2009/07/18/historiador-roger-chartier-diz-que-a-web-mudou-a-forma-deescrever/

Vidal, L. 2009. De nova Lisboa a Brasília: a invenção de uma capital (séculos XIX XX) (From New Lisbon to Brasilia: the invention of a capital city). Universidade de Brasilia, Brasilia, Brazil. 
